\title{
Formation and Regeneration of Geotrichum candidum Protoplasts
}

\author{
By ADRIANA M. P. DOOIJEWAARD-KLOOSTERZIEL, \\ J. H. SIETSMA* AND J. T. M. WOUTERS \\ Laboratory of Microbiology, University of Amsterdam, Plantage Muidergracht I4, \\ Amsterdam, The Netherlands
}

(Received 27 July 1972)

\begin{abstract}
SUMMARY
The formation of protoplasts from Geotrichum candidum, by means of a lytic enzyme complex of Streptomyces satsumaensis, was considerably stimulated by adding thiols, including dithiothreitol, 2-mercaptoethanol and cysteamine, to the incubation medium. Treatment of the mycelium with these compounds before incubation with lytic enzyme also enhanced protoplast formation, dithiothreitol giving the most rapid release of protoplasts. The same stimulating effect could be obtained with a proteolytic enzyme. These results suggest the presence of proteinaceous material in the outer layers of the hyphal wall. Geotrichum candidum protoplasts regenerated in liquid as well as solid media if a suitable osmotic stabilizer was present. Up to $20 \%$ of the protoplasts could grow into new mycelium.
\end{abstract}

\section{INTRODUCTION}

Geotrichum candidum produces an extracellular lipase (Wouters, I966). To understand the process of secretion of this enzyme Sietsma \& Wouters (I97I) have studied the composition of the wall because the wall may play an important role in secretion mechanisms (Lampen, 1968). Another way of approaching the problem of enzyme secretion is to study the process in cells without walls (Kuo \& Lampen, I 97I ; Liras \& Gascón, I97I). Sietsma \& Wouters (197I) have described the preparation of protoplasts from the mycelium of a young $(24 \mathrm{~h})$ culture of $G$. candidum. The present study was initiated to get protoplasts from mycelium of older cultures as well, for lipase production starts only after 5 to 7 days of cultivation (Wouters, I966). A study of the regeneration of protoplasts was also made.

\section{METHODS}

Cultures. The organism, Geotrichum candidum strain 5, and the culture conditions were as described previously (Sietsma \& Wouters, 197I). Culture flasks were incubated either on an orbital shaker or stationarily.

The lytic enzyme complex from Streptomyces satsumaensis I 399 was prepared as described by Sietsma \& Wouters (1971).

Preparation of protoplasts. In order to get a usable protoplast suspension the arthrospores must be removed from the mycelium. Therefore the culture was filtered over a sieve with a mesh of 32 to $40 \mu \mathrm{m}$. The mycelium stayed on this filter whereas the arthrospores were washed through by three to five rinsings with water and one with incubation medium (0.8 $\mathrm{M}-\mathrm{MgSO}_{4}$ in 5 mM-phosphate buffer, $\mathrm{pH} 5^{\cdot 8)}$. A suspension of mycelium was incubated in $\mathrm{I} 0 \mathrm{ml}$ of this medium with 30 to $50 \mathrm{mg}$ lytic enzyme (freeze-dried preparation) at $30{ }^{\circ} \mathrm{C}$. In some experiments the mycelium was pretreated with thiols, namely 2-mercaptoethanol, cysteamine, thioglycollate and dithiothreitol, or these compounds were added to the incubation medium.

* Present address : Botanisch Laboratorium, Kerklaan 30, Haren (Gr.), The Netherlands. 
Protoplasts prepared in this incubation medium sedimented only slowly at $\mathrm{I} 2000 \mathrm{~g}$. Therefore, after incubation, the mycelial debris was separated from the protoplasts by centrifugation at $\mathrm{I} 2000 \mathrm{~g}$ for $\mathrm{I} 5 \mathrm{~min}$ and washed twice with $0.8 \mathrm{M}-\mathrm{MgSO}_{4}$. The supernatant fluid and the washings were combined and the density of the liquid decreased by adding two volumes of $0.8 \mathrm{M}-\mathrm{NaCl}$. Afterwards the protoplasts could be sedimented at $4000 \mathrm{~g}$ for $\mathrm{I} 5 \mathrm{~min}$. Finally they were resuspended in $0.8 \mathrm{M}-\mathrm{MgSO}_{4}$ or $0.8 \mathrm{M}$-mannitol in $5 \mathrm{mM}$-phosphate buffer, $\mathrm{pH} 5 \cdot 8$.

Regeneration of protoplasts. In regeneration studies the protoplast suspension was supplemented with glucose and glutamate, both in a final concentration of Io $\mathrm{mm}$, and streptomycin sulphate $(250 \mu \mathrm{g} / \mathrm{ml})$ was added to prevent bacterial growth. The protoplast suspension was then incubated at $30{ }^{\circ} \mathrm{C}$ and samples withdrawn at intervals for examination by phasecontrast microscopy. For fluorescence microscopy, sedimented protoplasts were resuspended in a solution of $0.8 \mathrm{M}-\mathrm{MgSO}_{4}$ and $5 \mathrm{~mm}$-phosphate buffer, $\mathrm{pH} 5 \cdot 8$, containing $0 . \mathrm{I} \% \mathrm{Calco-}$ fluor White MR (Unilever Research Laboratories, Vlaardingen, The Netherlands) and examined with near u.v. light.

The percentage of protoplasts capable of regenerating was estimated by plating a known number of protoplasts on a solid medium and counting the number of colonies formed after $48 \mathrm{~h}$ of incubation at $28^{\circ} \mathrm{C}$. The medium was the Geotrichum candidum growth medium supplemented with $0.8 \mathrm{M}-\mathrm{mannitol}$ and $\mathrm{I} \%$ agar.

\section{RESULTS AND DISCUSSION}

\section{Protoplast formation}

To improve the release of protoplasts from yeasts or fungi the use of SH-containing compounds has been frequently recommended (Davies \& Elvin, I964; Bastide, Trave \& Bastide, 197I ; Sommer \& Lewis, I97I). Table I shows the effect of the addition of 2-mercaptoethanol, cysteamine, thioglycollate and dithiothreitol on protoplast formation from Geotrichum candidum mycelium. Almost total conversion into protoplasts occurred within $2 \mathrm{~h}$ when dithiothreitol or 2-mercaptoethanol (final concentration ro $\mathrm{mm}$ ) was added to the incubation mixture. Protoplast formation was slightly better from young mycelium than from older, lipase-producing mycelium. 2-Mercaptoethanol, in particular, exhibited a stronger stimulatory effect on protoplast formation from young mycelium. Duell, Inoue \& Utter (1964) have shown that pretreatment of stationary-phase cells of Saccharomyces cerevisiae with a higher concentration ( $140 \mathrm{~mm}$ ) of 2-mercaptoethanol stimulated protoplast formation considerably and similar treatment made older, lipase-producing mycelium of G. candidum as susceptible to the lytic enzymes as younger mycelium.

During protoplast formation, in the absence of sulphydryl-group-containing compounds, swellings appeared at several points on the hyphae, followed by the release of protoplasts (Sietsma \& Wouters, 197I). This was also observed with Aspergillus nidulans (Peberdy \& Gibson, I97I). In the presence of dithiothreitol or 2-mercaptoethanol swelling of hyphae could hardly be observed. The whole mycelial surface seemed to be attacked equally and the bulk of protoplasts emerged simultaneously (Fig. I $a$ ). Similar results are mentioned by May (I97I), who prepared protoplasts of Saccharomyces fragilis.

Pronase added to the incubation medium had the same stimulating effect on protoplast formation as had the thiol compounds (Table I). This suggests that the hyphal wall of Geotrichum candidum is covered with a layer of proteinaceous material which could be removed or loosened by thiol compounds, by their action of reducing S-S linkages in proteins (Nickerson, 1963). Chemical analysis of wall preparations has shown the presence of 


\section{Table I. Factors affecting formation of Geotrichum candidum protoplasts}

Protoplast formation was followed by phase-contrast microscopy during incubation with lytic enzyme in $0.8 \mathrm{M}_{-} \mathrm{MgSO}_{4}$ in $5 \mathrm{~mm}$-phosphate buffer, $\mathrm{pH} 5.8$. Pretreatment was performed in the same medium during $30 \mathrm{~min}$ at $30^{\circ} \mathrm{C}$. Young mycelium was from a $24 \mathrm{~h}$-shaken culture, old mycelium from a 5-day-stationary culture.

\begin{tabular}{|c|c|c|}
\hline \multicolumn{2}{|c|}{ Additions during } & \multirow{2}{*}{$\begin{array}{l}\text { Concentration } \\
(\mathrm{mM})\end{array}$} \\
\hline Incubation & Pretreatment & \\
\hline - & - & \\
\hline Cysteamine & - & 500 \\
\hline Cysteamine & - & 100 \\
\hline Cysteamine & - & 10 \\
\hline- & Cysteamine & 500 \\
\hline- & Cysteamine & 50 \\
\hline 2. Mercaptoethanol & - & 500 \\
\hline 2-Mercaptoethanol & - & 100 \\
\hline 2-Mercaptoethanol & - & IO \\
\hline - & 2-Mercaptoethanol & 500 \\
\hline- & 2-Mercaptoethanol & 170 \\
\hline Dithiothreitol & - & IO \\
\hline Thioglycollate & - & 50 \\
\hline Thioglycollate & - & 10 \\
\hline Pronase & - & $2 \mathrm{mg} / \mathrm{ml}$ \\
\hline
\end{tabular}

Protoplast formation from*

$-=$ after $10 \mathrm{~h}$ no protoplasts; $+=$ after $10 \mathrm{~h}$ few protoplasts; $++=$ after $6 \mathrm{~h}$ many protoplasts, no mycelium left $;++=$ after $2 \mathrm{~h}$ many protoplasts, no mycelium left; N.T. $=$ not tested.

about $7 \%$ protein (Sietsma \& Wouters, I97I). The susceptibility of the wall to lytic enzymes might depend on the nature of this protein layer, which may vary with age of culture and culture conditions.

\section{Regeneration of protoplasts}

Protoplast regeneration was generally performed in media stabilized by mannitol, since media stabilized with $\mathrm{MgSO}_{4}$ gave a lower level of regeneration, as observed for Pythium (Sietsma \& de Boer, 1973).

Regeneration of protoplasts in liquid medium occurred in a series of well-defined stages (Fig. I). The first visible signs of the regeneration process could be seen after $2 \mathrm{~h}$. Often protoplasts gave rise to a chain of irregular cells, which were still osmotically fragile (Fig. $\mathrm{I} b$ ). After $4 \mathrm{~h}$ of incubation protoplasts produced a hypha directly or through a chain of yeast-like cells (Fig. I $c$ ). At this stage the protoplasts attached to the hyphae were osmotically stable and dilution with distilled water did not cause lysis (Fig. I $d, e$ ).

Fluorescence microscopy showed that freshly prepared protoplasts from a 5-day-old culture were not stained with Calcofluor White MR, suggesting that the protoplasts were essentially free of hyphal wall glucans as Calcofluor is known to react principally with glucans (Preece, 1971). After $2 \mathrm{~h}$ of regeneration some fluorescent spots appeared on the protoplasts (Fig. I $f$ ). The terminal cell of a chain which grew out into a hypha (Fig. I $g$ ) and the tip of a growing hypha generally fluoresced most strongly. In an outgrown hypha the fluorescence was concentrated in distinct spots (Fig. I $h$ ), which might indicate that glucans are present only at distinct points on the surface or that this polymer layer is partly covered with a Calcofluor-insensitive outer layer (e.g. protein).

Less than $20 \%$ of protoplasts were able to regenerate into new mycelium on the agar medium. Protoplasts prepared in the presence of dithiothreitol from a 24 -h-shaken culture 

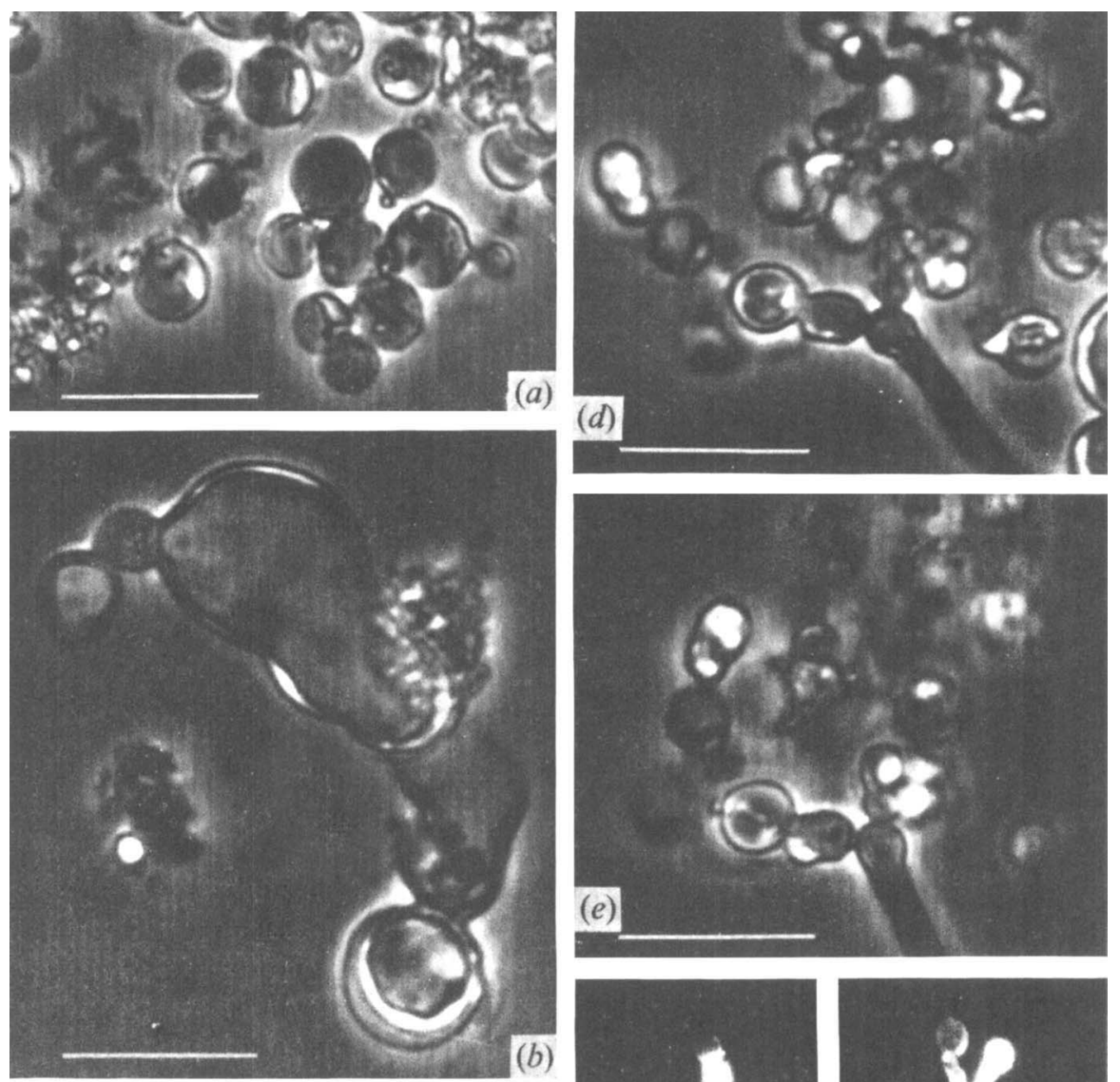

(b)
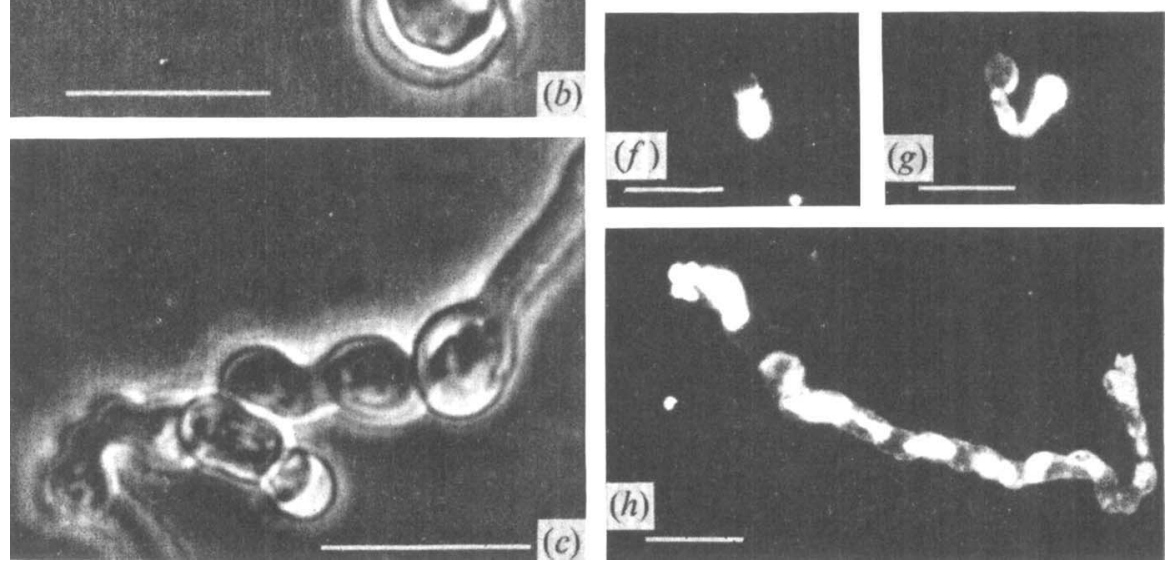

Fig. I. Formation and regeneration of Geotrichum candidum protoplasts. Scale markers represent Io $\mu \mathrm{m}$. (a) Protoplasts formed after $2 \mathrm{~h}$ of incubation with lytic enzyme in presence of $10 \mathrm{~mm}-$ dithiothreitol. (b) Irregularly formed cells after $2 \mathrm{~h}$ of regeneration. (c) Outgrowth into a hypha after $4 \mathrm{~h}$ of regeneration. (d) Outgrowing cells with hypha. (e) The same as $(d)$ after diluting with water. $(f)$ Regenerating protoplast after $2 \mathrm{~h}$ stained with Calcofluor White MR and photographed through a fluorescence microscope. $(g)$ After $4 \mathrm{~h}(h)$ After $12 \mathrm{~h}$. 
were not able to regenerate, but those from a 5-day-old, lipase-producing culture regenerated. The combined action of lytic enzyme complex and dithiothreitol on young mycelium could produce a protoplast on which no hyphal-wall remnants remain. These walls would then lack any 'primer' necessary for regeneration of wall polymers, as has been suggested by Sommer \& Lewis (I97I), who prepared protoplasts of Saccharomyces carlsbergensis in the presence of dithiothreitol.

This work was supported by a grant from the Netherlands Organization for the Advancement of Pure Research (Z.W.O.). The valuable assistance of J. L. B. Wesselink is very much appreciated. We are indebted to the department of bacteriology of the University of Amsterdam for the use of the fluorescence microscope and thank Unilever Research Laboratories in Vlaardingen for the gift of Calcofluor White MR.

\section{REFERENCES}

Bastide, J. M., Trave, P. \& Bastide, M. (1971). Étude de la paroi cellulaire de Candida macedoniensis: formation de protoplastes. Annales de L'Institut Pasteur 12I, 3I I-324.

DAVIES, R. \& Elvin, P. A. (1964). The effect of $\beta$-mercaptoethanol on release of invertase and formation of protoplasts of Saccharomyces fragilis. Biochemical Journal 93, 8P.

Duell, E. A., Inoue, S. \& UtTeR, M. F. (1964). Isolation and properties of intact mitochondria from spheroplasts of yeast. Journal of Bacteriology 88, $1762-1773$.

KUO, S. C. \& LAMPEN, J. O. (197I). Osmotic regulation of invertase formation and secretion by protoplasts of Saccharomyces. Journal of Bacteriology 106, 183-191.

Lampen, J. O. (I968). External enzymes of yeast: their nature and formation. Antonie van Leeuwenhoek 34, $\mathrm{I}-\mathrm{I} 8$.

LiRAS, P. \& GASCón, S. (197I). Biosynthesis and secretion of yeast invertase. Effect of cycloheximide and 2-deoxy-D-glucose. European Journal of Biochemistry 23, I60-165.

MAY, R. (197I). Isolationsbedingungen für Zellkerne aus Hefeprotoplasten. Zeitschrift für allgemeine Mikrobiologie II, I3I-r42.

Nickerson, W. J. (1963). Molecular bases of form in yeast. Bacteriological Reviews 27, 305-324.

Peberdy, J. F. \& Gibson, R. K. (1971). Regeneration of Aspergillus nidulans protoplasts. Journal of General Microbiology 69, 325-330.

Preece, T. F. (I97I). Fluorescent techniques in mycology. In Methods in Microbiology, vol. 4, pp. 509-516. Edited by C. Booth. London: Academic Press.

SietsMA, J. H. \& DE BOER, W. R. (I973). Formation and regeneration of protoplasts from Pythium PRL 2142. Journal of General Microbiology 74, 211-217.

Sietsma, J. H. \& Wouters, J. T. M. (197I). Cell wall composition and 'protoplast' formation of Geotrichum candidum. Archiv für Mikrobiologie 79, 263-273.

Sommer, A. \& LewIS, M. J.(197I). Effect of dithiothreitol on yeast: sphaeroplast formation and invertase release. Journal of General Microbiology 68, 327-335.

WOUTERS, J. T. M. (I966). Vetsplitsende activiteit van Geotrichum candidum en enkele andere microorganismen. Thesis of the University of Amsterdam. 